\title{
Młodzież w kryzysie - doświadczenie zaniedbania wśród adolescentek i adolescentów jako „zaniedbany” obszar teorii i badań
}

\begin{abstract}
Abstrakt
Doświadczanie przemocy ze strony rodziców - także jednej z form przemocy, jaką jest zaniedbanie - przyczynić się może do poważnego kryzysu emocjonalnego, silnie obciążającego pozytywny rozwój w okresie dorastania i ograniczający możliwości radzenia sobie z zadaniami rozwojowymi. Niestety nadal istnieją wątpliwości co do właściwego zdefiniowania zaniedbania młodzieży. Dostępne dane wskazują, że zaniedbanie nastolatków należy odróżnić od zaniedbania młodszych dzieci ze względu na różnice w potrzebach tych grup wiekowych, a co za tym idzie różnice w zachowaniach rodzicielskich wspierających rozwój oraz takich, które stanowią zagrożenie dla realizacji potrzeb młodych ludzi. Analiza dostępnej literatury świadczy o istnieniu luk $\mathrm{w}$ wiedzy na temat rozpowszechnienia zaniedbania wśród młodzieży oraz przyczyn i konsekwencji zaniedbania.
\end{abstract}

Słowa kluczowe: zaniedbanie, młodzież, kryzys emocjonalny.

\section{Young People in Crisis - the Experience of Being Neglected Among Adolescents as a Neglected Area of Theory and Research}

\begin{abstract}
Experiencing violence from parents (being neglected is a form of violence as well) may contribute to a serious emotional crisis affecting positive development in adolescence and limiting the ability to cope with developmental tasks. Unfortunately, there are still
\end{abstract}

\footnotetext{
* Uniwersytet Adama Mickiewicza, Wydział Studiów Edukacyjnych, Pracownia Promocji Zdrowia i Psychoterapii.
} 
doubts concerning a proper definition of neglect of young people. Available data indicate that neglect of teenagers should be distinguished from neglect of younger children because of differences in the needs of these age groups and, consequently, because of differences in parents' behaviours which support their development and which are a threat to young people's needs being met. Analysis of available literature reveals a gap in the knowledge about the occurrence of neglect of young people as well as its causes and consequences.

Keywords: neglect, adolescents, emotional crisis.

\section{Wprowadzenie}

W literaturze przedmiotu istnieją liczne badania dotyczące przemocy wobec dzieci, a także jednej z jej form, jaką jest zaniedbanie. Występuje jednak wyraźna luka zarówno w badaniach, jak i teorii dotyczącej specyfiki zaniedbania młodzieży, co utrudnia postawienie właściwej diagnozy oraz w konsekwencji zastosowanie właściwych form interwencji, mających na celu udzielenie pomocy. W literaturze przedmiotu znajdujemy postulaty, by nie „zaniedbywać zaniedbania” (Hicks, Stein 2015: 223-224). Postulat ten można rozszerzyć o apel, by nie zaniedbywać zaniedbania młodzieży. W publikacjach dotyczących maltretowania dziecka rzadko wyróżnia się grupy wiekowe, co powoduje, że dzieci i młodzi ludzie do 18. roku życia uważani są za jednorodną grupę (Rees, Stein, Hicks, Gorin 2011). Jednocześnie wyniki dostępnych badań wykazują istnienie różnic w zależności od wieku we wzorcach zaniedbania i jego konsekwencjach (Moran 2009). Wiele więc wskazuje na to, że zaniedbanie młodzieży powinno być analizowane oddzielnie od zaniedbania młodszych dzieci (Hicks, Stein 2015).

Doświadczenie zaniedbania potrzeb ze strony rodziców powoduje narastający stres, który prowadzi do kryzysu emocjonalnego, wymagającego zastosowania odpowiednich sposobów udzielania pomocy. Dlatego też niezwykle ważne jest właściwe rozpoznanie sytuacji, w jakiej znajdują się młodzi ludzie, gdyż pomoc z zewnątrz jest często niezbędna, żeby młody człowiek (i jego rodzina) mógł poradzić sobie z kryzysem. Z całą pewnością istnieje potrzeba zarówno ponownej analizy obecnych definicji zaniedbania w świetle różnic i perspektyw związanych z wiekiem, jak i pełniejszego zrozumienia szczególnych potrzeb młodzieży, która doświadcza zaniedbania (tamże).

W niniejszym artykule punktem wyjścia do analizy zaniedbania młodzieży będą zachowania rodzicielskie, które mogą sprzyjać dobremu funkcjonowaniu młodzieży lub też je utrudniać. Wiele z tych zachowań ze względu na ich znaczenie dla rozwoju będzie inaczej oceniane w przypadku dzieci niż nastolatków i dlatego też, ze względu na inne potrzeby rozwojowe tych grup wiekowych, inaczej oceniane będą zachowania rodziców zaniedbujące potrzeby małych dzieci, a inaczej młodych ludzi. W dalszej części pracy przedstawione zostaną badania dotyczące zaniedbania młodzieży, żeby wskazać na te obszary, które różnią je od zaniedbania młodszych dzieci. 


\section{Doświadczenie zaniedbania jako źródło kryzysu emocjonalnego}

Zaniedbanie jest jedną z form przemocy wobec dzieci i młodzieży obok przemocy fizycznej, psychicznej i wykorzystania seksualnego. Ma ono miejsce, gdy następuje zaniechanie, niewystąpienie czynności prawidłowej. W przypadku zaniedbania dopuszcza się pewien element niewinności sprawcy, gdyż może być ono aktem nie wyboru, a efektem braku możliwości. Zaniedbanie to niezapewnienie lub uniemożliwienie zaspokojenia potrzeb jednostce zależnej (Pospiszyl 1994). Jest ono często definiowane jako trwałe/uporczywe niezaspokajanie podstawowych fizycznych i/lub psychologicznych potrzeb, co może skutkować poważnymi negatywnymi konsekwencjami dla rozwoju i zdrowia.

Zaniedbywanie może występować na różnych etapach rozwoju, także w okresie prenatalnym i dotyczyć szerokiej gamy zachowań rodzicielskich. Wiąże się na przykład z niezdolnością rodzica lub opiekuna do zapewnienia odpowiedniej żywności, odzieży oraz schronienia. Zaniedbaniem jest także wyrzucenie z domu lub porzucenie. Także niezapewnienie ochrony dziecku przed fizycznym i emocjonalnym zranieniem lub niebezpieczeństwem jest formą zaniedbania, jak również brak odpowiedniego nadzoru oraz zapewnienia dostępu do właściwej opieki medycznej i/lub leczenia. Może ono również obejmować brak odpowiedzi na podstawowe potrzeby emocjonalne dziecka (Department for Education 2015).

Definiowanie zaniedbania jako trwałego niezaspokajania potrzeb dziecka lub adolescenta niesie za sobą zagrożenie pominięcia jednorazowych aktów działania, które mogą powodować bardzo poważne konsekwencje (Moran 2009), na przykład wyrzucenie nastolatka $\mathrm{z}$ domu. Warto podkreślić, że takie zachowanie wobec małego dziecka nie budziłoby społecznych wątpliwości co do jego szkodliwości, natomiast wobec na przykład siedemnastolatka, mimo wysoce prawdopodobnych bardzo niekorzystnych konsekwencji np. w sferze edukacji lub zdrowia, mogłoby być uznane za sposób na „kształtowanie niezależności”.

Według Szymona Wójcika (2013) zaniedbanie może być chroniczne lub incydentalne, w niektórych jednak sytuacjach nawet pojedyncze zaniechania mogą mieć dla dziecka fatalne skutki (np. w obszarze opieki zdrowotnej). Także Maria Kolankiewicz (2012) podkreśla, że zaniedbywanie może mieć charakter trwałej postawy, uporczywych zachowań albo też incydentalnego, ale brzemiennego w skutkach wydarzenia, które przyniosło szkodę dziecku.

Jan Howarth (2007) wyróżnił następujące rodzaje zaniedbań:

- Zaniedbanie medyczne - opiekunowie minimalizują lub negują chorobę oraz potrzeby zdrowotne, nie szukają odpowiedniej fachowej opieki, nie podają odpowiednich leków i nie stosują odpowiednich zabiegów medycznych.

- Zaniedbanie żywieniowe - opiekunowie nieodpowiednio odżywiają dziecko, doprowadzając z jednej strony do niedożywienia lub z drugiej strony do otyłości dziecięcej wynikającej z niezdrowej diety i braku ćwiczeń. 
- Zaniedbanie emocjonalne - wiąże się z brakiem odpowiedzi opiekuna na podstawowe potrzeby emocjonalne dziecka, w tym brak interakcji lub miłości.

- Zaniedbanie edukacyjne - to brak stymulacji, słabe lub brak wsparcia w obszarze edukacji. Wiąże się z tym, że opiekun nie zapewnia stymulującego środowiska, nie wykazuje zainteresowania edukacją dziecka w szkole, nie wspiera w nauce, a także nie przestrzega wymogów państwowych dotyczących obowiązku szkolnego.

- Zaniedbanie fizyczne - dotyczy niezapewnienia odpowiedniej odzieży, jedzenia, czystości i warunków życia. Może być to trudne do oceny ze względu na potrzebę odróżnienia zaniedbania od niedostatku oraz tego, co stanowią standardy odpowiedniej opieki fizycznej.

- Brak nadzoru i norm - wiąże się z brakiem zapewnienia odpowiedniego poziomu wsparcia i nadzoru w celu zapewnienia bezpieczeństwa fizycznego i ochrony przed szkodami. Może to wiązać się z opuszczeniem dziecka, porzuceniem go lub zostawieniem go $\mathrm{z}$ niewłaściwymi opiekunami, lub niestawianie odpowiednich granic zachowania, takich jak na przykład zgoda na spożywanie alkoholu przez nastolatków.

Definicje zaniedbania odnoszą się więc do „zaspokajania potrzeb”. Zazwyczaj nie jest tak, że potrzeby te nie są w ogóle zaspokajane - mogą być jednak zaspokajane w nieodpowiednim stopniu. Określenie, kiedy zaczyna się zaniedbanie, zależy wobec tego w dużej mierze od sformułowania normy, czyli minimalnych standardów opieki nad dzieckiem. Te standardy są zależne z kolei od norm przyjętych w danym społeczeństwie (Wójcik 2013).

Warto podkreślić, że młody człowiek doświadczający zaniedbania znajduje się w sytuacji kryzysowej. Kryzys jest stanem cechującym się dużym napięciem emocjonalnym, uczuciem przerażenia i bezradności, poczuciem wyczerpania własnych zasobów umożliwiających rozwiązanie doświadczanych problemów. W związku z tym jednostka wymaga pomocy z zewnątrz (Kubacka-Jasiecka 2005). Jak wynika z ustaleń badawczych przemoc jest jednym z najczęstszych źródeł kryzysów emocjonalnych o uwarunkowaniach zewnętrznych, interpersonalnych (Kubacka-Jasiecka, Ziarko 2016: 679).

Szczególnie trudna jest sytuacja dzieci i młodzieży doświadczającej przemocy ze strony rodziców, a więc osób najbliższych, odpowiedzialnych za ich rozwój. Kryzysy, których źródło stanowi przemoc w rodzinie nakładają się bowiem na chroniczny stres związany $\mathrm{z}$ pozostawaniem w bliskich relacjach ze sprawcą (tamże). Taka sytuacja jest szczególnie obciążająca dla młodzieży pozostającej nadal w sytuacji zależności od swoich rodziców. Kryzysy powiązane z przemocą zależą bowiem od relacji między sprawcą a ofiarą, a przemoc ze strony bliskich dewastuje poczucie bezpieczeństwa, wzajemne relacje, a także obraz Ja i świata (tamże). Ponadto jak dowodzą badania, zaniedbanie jest związane z przyszłym maltretowaniem i najpoważniejszym zagrażającym życiu znęcaniem się (Hindley, Ramchandani, Jones 2006). Często wiąże się z historią narastającego zaniedbania. Istnieją dowody, że zaniedbane dzieci są najbardziej narażone na poważne lub 
śmiertelne obrażenia (tamże). Zaniedbanie i emocjonalne nadużycie często wchodzą $\mathrm{w}$ interakcję $\mathrm{z}$ długotrwałą poważną dysfunkcją rodziny $\mathrm{w}$ taki sposób, że niezwykle trudno jest profesjonalistom rozpoznać, zrozumieć i adresować skuteczną pomoc, przynajmniej przed ostrym kryzysem, a czasem i tragedią (tamże).

\section{Zachowania rodzicielskie a rozwój psychospołeczny nastolatków}

Zaniedbanie nastolatków odnosi się w swej istocie do niezaspokajania przez opiekunów potrzeb młodzieży. Analiza tej formy przemocy musi więc być podjęta w kontekście tychże potrzeb, które w okresie dorastania są w niektórych aspektach znacząco różne od tych, jakie mają młodsze dzieci. Z tego względu relacje pomiędzy rodzicami i nastolatkami ulegają przekształceniu oraz zachowania rodzicielskie wobec adolescentów ewoluują w kierunku akceptacji coraz większej samodzielności młodzieży i partnerstwa w relacjach. Nie oznacza to jednak, że adolescenci i adolescentki nie potrzebują wsparcia zarówno emocjonalnego, jak i w podejmowaniu ważnych decyzji, miłości i troski. Podczas okresu dojrzewania dokonuje się wiele znaczących zmian rozwojowych, które to wyznaczają specyficzne potrzeby młodych ludzi - różne od potrzeb małych dzieci. Dlatego też w niniejszej pracy poddano analizie najważniejsze procesy rozwojowe, żeby móc nakreślić, które zachowania rodzicielskie zgodne są z potrzebami adolescentek i adolescentów, a które utrudniają rozwój lub też świadczą o zaniedbaniu potrzeb.

W aspekcie psychospołecznym najważniejsze osiągnięcia dojrzewania to kształtowanie się autonomii psychicznej i tożsamości. Dlatego też zmieniają się interakcje z rodzicami i znacząco zwiększa się wpływ grupy rówieśniczej. Nastolatki wiele czasu poświęcają na kontakty rówieśnicze, poszukiwanie akceptacji przez kolegów i koleżanki oraz uzyskiwanie satysfakcjonującej pozycji w grupie. Newmanowie w odniesieniu do okresu wczesnej adolescencji przyjęli jako podstawowy kryzys - identyfikacja z grupą versus alienacja, a dla etapu późnej adolescencji natomiast - tożsamość versus dyfuzja tożsamości. Zgodnie z tymi założeniami młodzież najpierw rozwija poczucie tożsamości grupowej jako wstęp do rozwoju poczucia tożsamości indywidualnej (Newman, Newman 1987). Dlatego też niezwykle ważna dla młodych ludzi jest możliwość kontaktów z innymi nastolatkami, co jest możliwe poprzez uzyskanie większej swobody oraz mniejszej kontroli ze strony rodziców w podejmowanych poza rodziną aktywnościach społecznych. Zdaniem Erika H. Eriksona (1997) to właśnie osiągnięcie tożsamości, a więc odpowiedź na pytanie „kim jestem?” jest głównym osiągnięciem rozwojowym tego okresu. Kontynuatorem pracy Eriksona był James Marcia, który opracował teorię statusów tożsamości (Marcia 1966) i uznał eksplorację oraz zaangażowanie za dwa podstawowe wymiary istotne dla zdefiniowania statusu jednostki w odniesieniu do osiągnięcia tożsamości. Odpowiedź na pytanie o własną tożsamość nastolatek musi uzyskać sam, a rodzice poprzez postawę zrozumienia dla jego sposobów na eksplo- 
rację możliwych rozwiązań tożsamościowych i wyborów życiowych mogą wspierać opisane przez Marcie procesy.

Psychologiczna autonomia natomiast obejmuje emocjonalną niezależność od rodziców, behawioralną autonomię w zakresie samodzielnego funkcjonowania, a także autonomię poznawczą obejmującą zaufanie do siebie w podejmowaniu decyzji (Collins, Gleason, Sesma 1995). Autonomię psychiczną najlepiej osiągnąć poprzez utrzymanie bliskich relacji z rodzicami, które to powinny ulec przekształceniom, a nie poprzez odrzucenie rodziców (Steinberg 1990). Adolescenci i ich rodzicie wspólnie tworzą relacje rodzinne poprzez dialektyczny proces negocjacji i zmian. Mimo że wraz z wiekiem nastolatki mają coraz większą możliwość samodzielnego kreowania własnej drogi życiowej, to jednak zachowania rodzicielskie nie pozostają bez wpływu na potencjał rozwojowy młodych ludzi. Wręcz przeciwnie, w literaturze przedmiotu istnieją silne dowody na znaczenie określonych zachowań rodzicielskich, które mogą sprzyjać rozwojowi młodych ludzi lub też stanowić dla niego obciążenie ze względu na zaniedbanie specyficznych potrzeb nastolatków (Jankowiak 2017). Gary W. Peterson i Kevin Ray Bush (2015) wymienili socjalizujące zachowania rodzicielskie i wskazali na ich znaczenie dla rozwoju adolescentek i adolescentów. Brak występowania niektórych z tych zachowań może być uznany za zaniedbanie potrzeb, na przykład brak okazywania pozytywnych uczuć. Natomiast występowanie innych, na przykład agresja fizyczna wobec nastolatka będąca częścią każącego rodzicielstwa, jest aktem przemocy fizycznej.

Pierwszym opisanym przez autorów socjalizującym zachowaniem rodzicielskim jest okazywanie ciepła i wsparcia przez rodziców. Wsparcie ze strony rodziców, troskliwość i opiekuńczość polega na zachowaniach, takich jak: dotykanie, przytulanie, całowanie, chwalenie, wyrażanie akceptacji, zachęcanie i wspólne spędzanie czasu. Jest związane z rozwojem praktycznie wszystkich aspektów kompetencji społecznych $\mathrm{w}$ okresie adolescencji. Należą do nich pozytywne poczucie własnej wartości, osiągnięcie tożsamości, autonomia, która współistnieje z dopasowaniem i zgodnością z rodzicami, a także przystosowaniem społecznym podczas dorosłości. Okazywanie ciepła i wsparcia wiąże się także z mniejszą ilością zaburzeń, takich jak np. zaburzenia lękowe, depresje, problemy z zachowaniem, a także rzadszymi konfliktami z rodzicami (Peterson, Bush 2015). Okazywanie ciepła, miłości i wsparcia jest więc nadal w okresie dorastania potrzebne dla prawidłowego rozwoju, a brak takich zachowań stanowi znaczące obciążenie dla dobrostanu młodzieży i może przyczynić się do powstawania zaburzeń. Zarówno z przekonań społecznych, jak i z literatury przedmiotu wynika, że okazywanie ciepła, miłości i troski jest niezwykle ważne dla prawidłowego rozwoju małych dzieci, np. w kontekście kształtowania się przywiązania (Bowlby 1969). I chociaż istnieją opracowania wskazujące na znaczenie bliskości i wsparcia ze strony rodziców dla rozwoju młodzieży (Peterson, Bush 2015), to jest ich znaczenie mniej niż prac poświęconych tym aspektom relacji między rodzicami a małymi dziećmi. 
Kolejne zachowania rodzicielskie nazwane są monitoringiem rodzicielskim. Jest to zestaw zachowań oraz zaangażowania uwagi rodziców na takich kwestiach, jak: miejsce pobytu nastolatka i podejmowane przez niego aktywności. Skuteczne monitorowanie oznacza, że rodzice muszą zachować jasny zestaw zasad dotyczących czasu, w którym młodzi ludzie powinni być w domu po czasie wolnym przeznaczonym na kontakty rówieśnicze, oraz miejsc, w których im nie wolno przebywać. Główną rolą monitoringu rodzicielskiego jest zapobieganie angażowaniu się nastolatków w problemowe relacje rówieśnicze, ryzykowne zachowania i działania dewiacyjne (Peterson, Bush 2015). Monitoring rodzicielski jest więc wyrazem troski rodziców o bezpieczeństwo i dobrostan ich nastoletnich dzieci, a brak zainteresowania sposobem spędzania czasu poza domem może znacząco zagrażać rozwojowi i zdrowiu nastolatków. Mimo że młodzież zdecydowanie nie potrzebuje takiego nadzoru ze strony rodziców jak mniejsze dzieci, to brak zainteresowania rodziców miejscem pobytu i sposobem spędzania wolnego czasu może skutkować negatywnymi konsekwencjami dla zdrowia i życia nastolatków. Brak monitoringu rodzicielskiego dostosowanego do wzrastającej niezależności adolescentów można więc uznać za objaw zaniedbania. Przyznawanie psychologicznej autonomii to zachowania rodziców szczególnie ważne na tym etapie rozwoju. Jest to wykorzystywanie nierepresyjnych zachowań, demokratycznego sposobu dyscyplinowania i zachęcanie nastolatków do wyrażania swojej indywidualności w obrębie rodziny. Zachęcanie do autonomii jest sposobem do rozwoju poczucia własnej wartości, poczucia kompetencji i poczucia wiary w siebie (tamże). W okresie adolescencji umożliwienie młodzieży rozwijania autonomii przy jednoczesnym wspieraniu i okazywaniu uczuć jest niezwykle ważne dla przyszłych sukcesów życiowych. „Ważnym zadaniem jest uwolnienie się spod opieki i wpływu rodziców, a optymalnym efektem rozwoju w tej fazie powinno być ukształtowanie autonomicznej, spójnej osobowości" (Mary, Nordholt 2004: 29). Przyznawanie autonomii nie ma jednak oznaczać pozostawienia młodzieży bez wsparcia emocjonalnego i instrumentalnego. Młodzi ludzie nadal mogą bowiem potrzebować wskazówek od rodziców w podejmowaniu ważnych decyzji życiowych i ich troski. Mimo tego zbyt ścisła kontrola i dominacja są zachowaniami, które utrudniają realizację ważnych potrzeb rozwojowych $\mathrm{w}$ okresie dorastania, związanych z samodzielnością, niezależnością i indywiduacją.

Zachowaniem rodzicielskim zdecydowanie niekorzystnym dla kształtującej się autonomii młodych ludzi jest nachalna kontrola psychologiczna. Ma ona na celu nadzór nad młodzieżą, lecz bez poszanowania autonomii. Takie podejście rodziców zniechęca do indywidualizmu, zakłóca psychologiczną niezależność (szczególnie ważną w okresie adolescencji) i rozwój emocjonalny. Częste korzystanie z nachalnej kontroli psychologicznej jest związane przede wszystkim z rozwojem zaburzeń internalizacyjnych u młodzieży, takich jak: depresja, wycofanie, samotność oraz zaburzenia jedzenia, negatywne postrzeganie siebie, niższa samoskuteczność i trudności w rozwoju tożsamości. Konsekwencją uciążliwej kontroli psychologicz- 
nej jest nadmierne uzależnienie młodzieży, hamowanie autonomii i emocjonalnej niezależności od rodziców i innych dorosłych (Peterson, Bush 2015). Nachalna kontrola psychologiczna stoi więc w opozycji do potrzeby separacji i indywiduacji, utrudnia kształtowanie poczucia niezależnej tożsamości i niezależności.

Natomiast kolejne zachowanie rodzicielskie, jakim jest argumentowanie własnego stanowiska, odwołuje się do rosnącej dojrzałości, zdolności do rozumienia i dobrowolnego przyjęcia punktu widzenia rodzica - lub też negocjowania z rodzicami własnych pomysłów, a także wyborów życiowych i przekonanie do nich rodziców. Zastosowanie argumentów podczas dyskusji z nastolatkami pomaga młodym ludziom zrozumieć, dlaczego zasady są niezbędne, dlaczego ich zachowanie jest niewłaściwe z punktu widzenia rodziców, a także, jak wpływa ono na innych (tamże). W okresie dojrzewania następuje rozwój operacji formalnych, które charakteryzują się bardziej logicznym, abstrakcyjnym i mniej egocentrycznym myśleniem niż operacje konkretne, typowe dla młodszych dzieci. Dzięki temu dorastający głębiej wnikają w problemy, dostrzegają różne opcje, stawiają dociekliwe pytania (Obuchowska 2005: 173). Stosowanie argumentów przez rodziców - ale także otwartość na argumenty młodych ludzi - pozwala rozwijać poznawcze umiejętności i sprawia, że młodzież nie tylko będzie funkcjonować na wyższych rozwojowo, bardziej adaptacyjnych poziomach myślenia, ale także może rozwijać kompetencje społeczne poprzez negocjowanie i przedstawianie własnego stanowiska.

Ostatnie z wymienionych przez Petersona i Busha zachowań jest każące rodzicielstwo. To werbalne lub fizyczne surowe naciski stosowane przez rodziców, aby wpłynąć na zachowanie i wewnętrzne cechy nastolatków. Działania te obejmują zarówno wykorzystanie dominacji, jak i siły, by narzucić swoją wolę. Mogą także zawierać agresję werbalną, a także kary cielesne (np. klapsy) oraz inne formy przemocy. Stosowanie przemocy w rodzinie jest jednym z najczęściej wymienianych czynników rodzinnych powstawania zaburzeń w okresie dzieciństwa i adolescencji. Efekty takich metod wychowawczych to: niskie poczucie własnej wartości, depresja, trudności w prawidłowym rozwoju moralnym, niskie sukcesy edukacyjne, zwiększone ryzyko uzależnień oraz podejmowania zachowań łamiących prawo. Stosowanie kar fizycznych przez rodziców powoduje tylko jeden pozytywny skutek (tj. natychmiastowe podporządkowanie) oraz wiele niezamierzonych negatywnych konsekwencji (Peterson, Bush 2015).

Socjalizujące zachowania rodzicielskie powinny więc wspierać rozwój w okresie adolescencji, to znaczy dawać młodzieży szansę na eksplorację rozwojową w obszarze własnej tożsamości i możliwość podejmowania autonomicznych decyzji przy jednoczesnym wspieraniu, okazywaniu zainteresowania i miłości. Niewystępowanie takich zachowań rodzicielskich powoduje trudności $\mathrm{w}$ realizacji zadań rozwojowych $\mathrm{w}$ okresie dojrzewania i może świadczyć o zaniedbaniu potrzeb adolescentek i adolescentów (Jankowiak 2017). Doświadczenie przemocy w rodzinie, jakim jest zaniedbanie, może powodować silny kryzys emocjonalny, poważnie obciążający możliwości młodych ludzi w radzeniu sobie z zadaniami rozwojo- 
wymi okresu dorastania. Kryzys emocjonalny nakładający się na kryzys rozwojowy występujący w okresie dorastania będzie stanowić obciążenie dla młodych ludzi i przyczyniać się do bardziej kompromisowych - a więc mniej korzystnych - rozwiązań adaptacyjnych. Młodzi ludzie, którzy będą zmuszeni radzić sobie z takimi nienormatywnymi trudnościami wejdą w kolejne etapy rozwojowe mniej przygotowani niż ich rówieśnicy do radzenia sobie z kolejnymi wyzwaniami.

\section{Zaniedbanie młodzieży - co wiemy... i dlaczego nie wiemy więcej?}

Zaniedbanie, mimo że jest uznawane za formę przemocy, która jest istotnym czynnikiem ryzyka powstawania zaburzeń okresu dorastania, bywa pomijane w opracowaniach naukowych dotyczących okresu adolescencji, częściowo z powodu uznania znaczenia autonomii na tym etapie rozwoju. Tak więc zaniedbanie, mimo że ma szkodliwy wpływ na całe życie, jest rzadko rozpoznawane u młodych ludzi (Naughton, Cowley, Tempest, Maguire, Mann, Kemp 2017). Ponadto różne formy przemocy występują jednocześnie. Na przykład przemoc fizyczna często współistnieje z zaniedbaniem emocjonalnym i psychologicznym, szczególnie w formie emocjonalnej niedostępności, obojętności lub chłodu (Gardner 2008). Warto podkreślić, że w literaturze przedmiotu w odniesieniu do zaniedbania i przemocy emocjonalnej pojawiają się głosy, że stwarzają one problemy z precyzyjnym zdefiniowaniem i dlatego trudno uczynić je przedmiotem badań naukowych, a także ustalić skalę tego zjawiska (Iniewicz, Ryżanowska 2011). Na przykład w badaniu prowadzonym przez Phila Rawsa (2016) jeden na siedmiu nastolatków w wieku 14-15 lat, którzy mieszkali z opiekunami, było zaniedbanych w jednym lub kilku obszarach. Opiekunowie nie wykazywali zainteresowania ich życiem, nie okazywali im ciepła, nie podejmowali żadnego wysiłku, by monitorować ich zachowanie lub ich chronić, nie dbali także o ich zdrowie.

Jak już wcześniej zaznaczono, młodsze dzieci dużo bardziej potrzebują opieki i kontroli ze strony rodziców niż nastolatki, a potrzeby tych grup różnią się. Także możliwości podejmowania decyzji i wpływu na kontekst rozwoju małych dzieci i nastolatków są zdecydowanie różne. Jak pisze Anna Brzezińska:

w miarę rozwoju wzrastają więc zakres i siła naszego oddziaływania na otoczenie, zostają opanowane nowe, efektywniejsze sposoby zaspokajania swoich potrzeb i spełniania wymagań otoczenia z jednej strony, ale z drugiej - sposoby modyfikowania lub nawet radykalnej zmiany tego otoczenia i dostosowania go do swoich planów i zamierzeń (Brzezińska 2015: 23).

Ze względu na owe różnice w możliwościach samodzielnego funkcjonowania i samodzielnego zaspokajania potrzeb, definiowanie zaniedbania dla okresu dzieciństwa od urodzenia do końca okresu adolescencji stwarza poważne trudności. Na 
przykład zaniedbanie nadzoru różni się w zależności od wieku dziecka, a monitorowanie i nadzór rodzicielski w okresie dorastania muszą być zrównoważone przez zachowania rodzicielskie, które pomagają wspierać autonomię i niezależność nastolatka. Ponadto, mimo że w definicjach zaniedbania zazwyczaj podkreślany jest proces niezaspokajania potrzeb (Wójcik 2013), to należy pamiętać, że w przypadku młodzieży zaniedbanie często bywa aktem jednorazowym, np. nakaz opuszczenia domu, a nie powtarzającym się doświadczeniem.

Nadal brakuje badań dotyczących przyczyn zaniedbania młodzieży, które odróżniałyby nastolatków od młodszych dzieci. Leslie Hicks i Mike Stein wskazują jednak na pewne różnice związane $\mathrm{z}$ wiekiem, które mogą być specyficzne dla adolescentów i adolescentek. Na przykład zwiększone kompetencje społeczne młodzieży prowadzą często do większej odpowiedzialności, co w niektórych okolicznościach może spowodować, że pełnią rolę opiekuna w rodzinie, zarówno dla rodzeństwa, jak i rodziców. W konsekwencji społeczne, emocjonalne i rozwojowe potrzeby młodych ludzi mogą zostać przeoczone. Ponadto nastolatki częściej niż młodsze dzieci mają okazję mieszkać w rodzinach, gdzie zachodzą ważne zmiany strukturalne, np. w wyniku rozwodu. Może to prowadzić do zwiększonego ryzyka zaniedbania emocjonalnego na przykład, gdy nowy partner rodzica wyklucza emocjonalnie nastolatka z rodziny (Hicks, Stein 2015).

Więcej wiadomo na temat konsekwencji zaniedbania. Mimo że - jak wskazują niektóre wyniki badań - młodzież doświadczająca zaniedbania ma mniej symptomów stresu pourazowego niż adolescenci doświadczający maltretowania fizycznego i seksualnego (Wechsler-Zimring, Kearney 2011), to w przypadku doświadczenia zaniedbania wykazano bardzo wiele niekorzystnych następstw. Na przykład istnieje zwiększone prawdopodobieństwo antyspołecznych zachowań, takich jak np. popełnianie przestępstw przez młodych ludzi (Thornberry, Ireland, Smith 2001). Wyniki dostępnych badań wskazują, że zaniedbane nastolatki mają trudności w obszarze kompetencji społeczno-emocjonalnych (Moreno-Manso, García-Baamonde, Guerrero-Barona, Godoy-Merino, Blázquez-Alonso, González-Rico 2016), częściej niż ich rówieśnicy porzucają edukację i nadużywają substancji psychoaktywnych (Erickson, Egeland 2002), mogą także próbować popełnić samobójstwo (Cullingford, Morrison 1997). Badania wykazały również, iż zaniedbane nastolatki wykazywały zaburzenia internalizujące (depresja, symptomy pourazowe, lęk, zaburzenia snu) oraz było bardziej prawdopodobne, że zajdą w ciążę w okresie późnej adolescencji (Naughton, Cowley, Tempest, Maguire, Mann, Kemp 2017). Młodzież doświadczająca zaniedbania częściej niż ich rówieśnicy doświadczała przemocy na randkach (Wekerle, Leung, Wall, MacMillan, Boyle, Trocme, Waechter 2009; Tyler, Brownridge, Melander 2011).

Wyniki badań prowadzonych przez Rawsa wskazują, że zgłaszające zaniedbanie młode osoby miały niższe poczucie dobrostanu niż ich rówieśnicy i większą od nich skłonność, by zachowywać się w sposób, który może narażać ich zdrowie lub 
ich możliwości rozwojowe. Badanie to ujawniło, że zaniedbane nastolatki mają tendencję do zgłaszania wątpliwości dotyczących własnych kompetencji, mają niską wiarę w to, że ich życie jest dla kogoś ważne, były pesymistycznie nastawione do przyszłości i niezadowolone z życia ogólnie. Jednocześnie w sygnalizowanych badaniach stwierdzono, że wysoki poziom nadzoru nie był związany z wysokim poziomem dobrostanu młodzieży. Ustalenie to stoi w sprzeczności z powszechnie przyjmowanymi założeniami, że więcej opieki i troski rodzicielskiej jest dla dobrostanu dzieci korzystne. Wskazuje to na znaczenie autonomii i możliwości dokonywania samodzielnych wyborów jako szczególnie ważne dla młodzieży. Może sugerować, zdaniem Rawsa, że w trakcie okresu dorastania młodzież będzie odbierać pytania dotyczące ich życia poza domem jako inwazyjne. Takie zachowania rodzicielskie mogą być uznawane przez młodych ludzi za sposób na kontrolę ich zachowań i ograniczanie autonomii, co uważają za niemile widziane (Raws 2016).

W badaniach dotyczących zaniedbania nastolatków, gdy pytano młodych ludzi w grupach fokusowych, jak według nich powinna być zdefiniowana ta forma przemocy, młodzież rozszerzyła „oficjalną” definicję zaniedbania, która kładzie nacisk na zaspokojenie podstawowych potrzeb. Na przykład stwierdzili, że do zaniedbania dochodzi, gdy rodzice lub opiekunowie nie zapobiegają otyłości u dzieci, nie wyposażają dzieci w umiejętności społeczne, nie uczą samodzielnego dbania o siebie oraz znajomości norm w relacjach międzyludzkich. Młodzi uważają, że do zaniedbania dochodzi, gdy rodzice nadają priorytet nowemu partnerowi ponad własne dzieci lub regularnie wykorzystują je do opieki nad młodszym rodzeństwem. Młodzi ludzie rozważali także różne scenariusze, w których, na przykład, dzieci pozostawiono bez nadzoru przez okres trzech godzin w ciągu dnia lub na noc, lub zobowiązano je do gotowania własnych posiłków czy też karmiono ich dietą typu fast food. Dyskusje dotyczyły tego, czy różne sytuacje stanowiły zaniedbanie w zależności od wieku zaangażowanego dziecka (które może mieć 2, 9, 12 lub 15 lat). W sytuacjach, w których dziecko miało 12 lub 15 lat, młodzieży trudno było dojść do konsensusu, co jest zaniedbaniem, a co nie. Grupy doszły do wniosku, że zaniedbanie jest bardziej zdeterminowane przez zdolności, umiejętności i potrzeby, a nie bezwzględny wiek. Młodzi ludzie, którzy uczestniczyli w badaniach, zdecydowali, że to, co jest zaniedbaniem, zależy od tego, jak jednostka się czuje lub jak tego doświadcza (Rees, Stein, Hicks, Gorin 2011).

Z konkluzji poczynionych przez adolescentów i adolescentki wynika, że umiejętności, możliwości i subiektywna ocena jednostki są ważniejsze niż podejmowana w artykule kwestia wieku. W tym kontekście wyłania się ważny aspekt dotyczący zindywidualizowanego podejścia do każdej osoby zagrożonej zaniedbaniem - diagnozy potrzeb, zasobów oraz czynników ryzyka działających w konkretnym przypadku. Taki sposób postępowania, przy jednoczesnym poszukiwaniu pewnych uniwersalnych dla grup wiekowych rozwiązań, może przyczynić się do lepszego rozumienia problematyki zaniedbania dzieci i młodzieży. 


\section{Podsumowanie}

Przytoczone wyniki badań wskazują, że istnieją luki w wiedzy na temat zaniedbania nastolatków zarówno w kontekście przyczyn, jak i konsekwencji doświadczania zaniedbania. Dane, które posiadamy, potwierdzają jednak potrzebę odróżnienia zaniedbania dzieci od zaniedbania nastolatków, gdyż wiele z konsekwencji zaniedbania będzie specyficznych dla adolescentek i adolescentów, np. przemoc na randkach, nastoletnia ciąża, porzucanie edukacji. Budowanie mocniejszej bazy wiedzy w odniesieniu do zaniedbanej młodzieży umożliwi wybór bardziej efektywnych interwencji dla tej grupy wiekowej.

Przytoczone dane wskazują na szkodliwe skutki zaniedbania młodzieży, takie jak: zachowania internalizujące, myśli samobójcze, wiktymizacja, przemoc na randkach i przestępczość. Podejmowanie tych zachowań przez zaniedbanych nastolatków może być źle zinterpretowane przez otoczenie społeczne jako tylko i wyłącznie zachowanie problemowe wymagające zastosowania odpowiednich form kontroli i kary, a nie jako skutek doświadczanej przemocy. Ważne jest, żeby osoby odpowiedzialne za rozwój, zdrowie i edukację nastolatków nie oceniały tych zachowań bez prób zrozumienia ich przyczyn. Właściwa diagnoza doświadczanych trudności umożliwi zastosowanie odpowiednich interwencji i pomocy w radzeniu sobie z kryzysem.

\section{Bibliografia}

Badura-Madej W., Dobrzyńska-Mesterhazy A. (2000) Przemoc w rodzinie. Interwencja kryzysowa i psychoterapia, Kraków, Wydawnictwo Uniwersytetu Jagiellońskiego.

Bowlby J. (1969) Attachment and Loss: Attachment, New York, Basic Books.

Brzezińska A. I. (2015) Jak przebiega rozwój człowieka? w: Psychologiczne portrety człowieka. Praktyczna psychologia rozwojowa, A. I. Brzezińska (red.), Gdańsk, GWP.

Collins W. A., Gleason T., Sesma A. (1995) Internalization, autonomy, and relationships: Development during adolescence w: Parenting and children's internalization of values: A handbook of contemporary theory, J. E. Grusec, L. Kuczynski (red.) New York, Wiley, s. 78-99.

Cullingford J., Morrison J. (1997) The Relationship between Criminality and Home Background, „Children and Society”, 11 (3), s. 157-172.

Erikson E. H. (1997) Dzieciństwo i społeczeństwo, Poznań, Rebis.

Erickson M. F., Egeland B (2002) Child Neglect w: The APSAC Handbook on Child Maltreatment, J. E. B. Myers, L. Berliner, J. Briere, C. T. Hendrix, C. Jenny, T. A. Reid (red.) Thousand Oakes, Sage. 
Hicks L., Stein M. (2015) Understanding and working with adolescent neglect: perspectives from research, young people and professionals, „Child and Family Social Work”, 20 (2), s. 223-233.

Hindley N., Ramchandani P. G., Jones D. P. H. (2006) Risk factors associated for recurrence of maltreatment, „Archives of Disease in Childhood”, 91 (9), s. 744-752.

Horwath J. (2007) Child Neglect: Identification and Assessment, London, Palgrave Macmillan.

Iniewicz G., Ryżanowska D. (2011) Przemoc i zaniedbanie w: Psychologia zdrowia dzieci i młodzieży, W. Pilecka (red.), Kraków, Wydawnictwo Uniwersytetu Jagiellońskiego.

Jankowiak B. (2017) Socjalizujące zachowania rodzicielskie a rozwój adolescentów $\mathrm{w}$ : Rodzinne (re)konstrukcje i transmisje $w$ perspektywie biograficznej, K. Kuryś-Szyncel (red.), Poznań, Wydawnictwo Naukowe UAM, s. 91-103.

Kolankiewicz M. (2012) Zaniedbywanie dzieci, „Dziecko Krzywdzone. Teoria, badania, praktyka", nr 2 (39), s. 81-94.

Kubacka-Jasiecka D. (2005) Interwencja kryzysowa w: Psychologia kliniczna, t. 2, H. Sęk (red.), Warszawa, Wydawnictwo Naukowe PWN, s. 244-272.

Kubacka-Jasiecka D., Ziarko M. (2016) Pomoc psychologiczna w różnych typach kryzysu w: Psychologia kliniczna, L. Cierpiałkowska, H. Sęk (red.), Warszawa, Wydawnictwo Naukowe PWN.

Marcia J. E. (1966) Development and Validation of Ego - Identity Status, „Journal of Personality and Social Psychology", 3 (5), s. 551-558.

Mary M., Nordholt H. (2004) Ukryty plan życia, Warszawa, Wydawnictwo Lekarskie PZWL.

Moran P. (2009) Neglect: research evidence to inform practice, London, Action for Children.

Moreno-Manso J. M., García-Baamonde M. E., Guerrero-Barona E., Godoy-Merino M. J., Blázquez-Alonso M., González-Rico P. (2016) Perceived emotional intelligence and social competence in neglected adolescents, „Journal of Youth Studies”, 19 (6), s. 821835.

Naughton A. M., Cowley L. E., Tempest V., Maguire, S. A., Mann M. K., Kemp A. M. (2017) Ask Me! self-reported features of adolescents experiencing neglect or emotional maltreatment: a rapid systematic review, "Child: Care, Health and Development", 43 (3), s. 348-360.

Newman B. M., Newman P. R. (1987) Development through life: a psychosocial approach, California, Brooks/Cole Publishing Company. 
Obuchowska I. (2005) Adolescencja w: Psychologia rozwoju człowieka. Charakterystyka okresów życia człowieka, B. Harwas-Napierała, J. Trempała (red.), Warszawa, Wydawnictwo Naukowe PWN, s. 163-202.

Peterson G. W., Bush K. R. (2015) Families and Adolescent Development w: Handbook of Adolescent Behavioral Problems: Evidence-Based Approaches to Prevention and Treatment, T. P. Gullotta, R. W. Plant, M. A. Evans (red.), New York, Springer Science+Business Media.

Pospiszyl I. (1994) Przemoc w rodzinie, Warszawa, Wydawnictwa Szkolne i Pedagogiczne.

Raws P. (2016) Understanding Adolescent Neglect: Troubled Teens A study of the links between parenting and adolescent neglect, London, Children's Society.

Rees G., Stein M., Hicks L. Gorin S. (2011) Adolescent Neglect: Research, Policy and Practice, London, Jessica Kingsley Publishers.

Steinberg L. T. (1990) Interdependence in the family: Autonomy, conflict, and harmony in the parent - adolescent relationship w: At the threshold: The developing adolescent, S. S. Feldman, G. L. Elliott (red.) Cambridge, MA, Harvard University Press, s. 255-276.

Thornberry T. P., Ireland T. O., Smith C.A. (2001) The importance of timing: the varying impact of childhood and adolescent maltreatment on multiple problem outcomes, „Development and Psychopathology”, 13 (4), s. 957-979.

Wechsler-Zimring A., Kearney C. A. (2011) Posttraumatic Stress and Related Symptoms Among neglected and physically and sexually maltreated adolescents, "Journal of Traumatic Stress", 24 (5), s. 601-604.

Wekerle C., Leung E., Wall A. M., MacMillan H., Boyle M., Trocme N., Waechter R. (2009) The contribution of childhood emotional abuse to teen dating violence among child protective services-involved youth, „Child Abuse \& Neglect”, 33 (1), s. 45-58.

Wójcik S. (2013) Przemoc w rodzinie, zaniedbanie, wiktymizacja pośrednia. Wyniki Ogólnopolskiej diagnozy problemu przemocy wobec dzieci, „Dziecko Krzywdzone. Teoria, badania, praktyka", 12 (3), s. 40-62.

\section{Źródła internetowe}

Department for Education (2015) Working together to safeguard children: A guide to inter-agency working safeguard and promote the welfare of children. London: Department for Education, https://assets.publishing.service.gov.uk/government/uploads/ system/uploads/attachment_data/file/779401/Working_Together_to_SafeguardChildren.pdf

Gardner R. (2008) Developing an effective response to neglect and emotional harm to children, Norwich, UEA/NSPCC, http://www.nspcc.org.uk/Inform/research/ nspccresearch/completedresearch/DevelopingAnEffectiveResponseToNeglectPDF_wdf56700.pdf 